IZA DP No. 8554

Sufficient Statistic or Not? The Elasticity of Taxable Income in the Presence of Deduction Possibilities

Philipp Doerrenberg

Andreas Peichl

Sebastian Siegloch

October 2014 


\title{
Sufficient Statistic or Not? \\ The Elasticity of Taxable Income in the Presence of Deduction Possibilities
}

\author{
Philipp Doerrenberg \\ ZEW Mannheim, \\ CGS at University of Cologne and IZA \\ Andreas Peichl \\ ZEW Mannheim, \\ University of Mannheim, IZA and CESifo
}
Sebastian Siegloch
University of Mannheim,
IZA, ZEW and CESifo
Discussion Paper No. 8554
October 2014

\author{
IZA \\ P.O. Box 7240 \\ 53072 Bonn \\ Germany \\ Phone: +49-228-3894-0 \\ Fax: +49-228-3894-180 \\ E-mail: iza@iza.org
}

\begin{abstract}
Any opinions expressed here are those of the author(s) and not those of IZA. Research published in this series may include views on policy, but the institute itself takes no institutional policy positions. The IZA research network is committed to the IZA Guiding Principles of Research Integrity.

The Institute for the Study of Labor (IZA) in Bonn is a local and virtual international research center and a place of communication between science, politics and business. IZA is an independent nonprofit organization supported by Deutsche Post Foundation. The center is associated with the University of Bonn and offers a stimulating research environment through its international network, workshops and conferences, data service, project support, research visits and doctoral program. IZA engages in (i) original and internationally competitive research in all fields of labor economics, (ii) development of policy concepts, and (iii) dissemination of research results and concepts to the interested public.
\end{abstract}

IZA Discussion Papers often represent preliminary work and are circulated to encourage discussion. Citation of such a paper should account for its provisional character. A revised version may be available directly from the author. 


\section{ABSTRACT}

\section{Sufficient Statistic or Not? The Elasticity of Taxable Income in the Presence of Deduction Possibilities*}

The elasticity of taxable income (ETI) is often interpreted as a sufficient statistic to assess the welfare costs of taxation. Building on the conceptual framework of Chetty (2009), we show that this assertion does no longer hold for tax systems with deduction possibilities if (i) deductions generate externalities and (ii) deductions are responsive to tax rate changes. While the first condition should arguably hold for almost any imaginable tax deduction, we provide a thorough empirical examination of the second condition. Relying on rich German panel data from administrative tax records, we exploit several tax reforms that were implemented in Germany between 2001 and 2008. Our baseline estimates indicate an overall $\mathrm{ETI}$ of 0.49 and an elasticity of deductions with respect to the net-of-tax rate of -2.80 . Given that the majority of deductions in the German income tax system generate externalities, our non-zero deduction elasticity suggests that the ETI is not sufficient to calculate the welfare cost of taxation.

JEL Classification: H24, H31

Keywords: elasticity of taxable income, deductions, tax expenditures, sufficient statistic, administrative data, Germany

Corresponding author:

Andreas Peichl

ZEW Mannheim

$L 7,1$

68161 Mannheim

Germany

E-mail: peichl@zew.de

\footnotetext{
* We are grateful to Michelle Hansch and Carina Woodage for very valuable research assistance and to the Research Data Lab of the German Federal Statistical Agency, and especially Rafael Beier and Stefanie Uhrich, for steady support in accessing the data. We thank Caroline Weber for sharing her Stata code. David Agrawal, Soeren Blomquist, Denvil Duncan, Clemens Fuest, Roger Gordon, Jarkko Harju, Eckhard Janeba, Max Löffler, Tuomas Matikka, Johannes Hermle, Joel Slemrod, Caroline Weber, Carina Woodage, and participants at the 2014 NBER TAPES meeting (Vienna), IIPF 2014 (Lugano), and MaTax 2014 (Mannheim) provided helpful comments and suggestions on earlier drafts.
} 


\section{Introduction}

The large literature on the elasticity of taxable income (ETI) estimates the responsiveness of taxpayers to income tax changes (see Saez et al. 2012 for an overview). Recent studies find elasticities with respect to the net-of-tax rate in the range of about 0.1 to 0.8 (e.g., Weber 2014 and Kleven and Schultz 2014), suggesting that income taxpayers are sensitive to taxes and alter their taxable income in response to varying tax rate changes. Following the seminal contributions by Feldstein (1995, 1999), the literature usually uses such ETI estimates as a "sufficient statistic" to estimate the deadweight loss of income taxes. This assumes that all types of behavioral responses that affect taxable income, such as labor supply adjustments, charitable donations, or illegal evasion, have the same impact on welfare, and thus can be boiled down to one single number, the ETI.

Chetty (2009), however, shows that the channel along which taxable income responses occur may make a difference for the efficiency losses induced by income taxes. If behavioral adjustments to reduce taxable income generate externalities such as transfers to other agents in the economy, losses to overall welfare are lower compared to cases in which behavioral adjustments are associated with real resource costs. In the extreme case in which a behavioral adjustment produces a pure externality and does not impose any resource costs, the gross income elasticity, rather than the ETI, becomes the relevant parameter for welfare analysis. In a more general case with externalities and resource costs, Chetty's analysis shows that the welfare loss is a weighted average of the ETI and the gross income elasticity. These results imply that it is important for welfare analyses of tax reforms to disentangle the relative importance of the single adjustment channels that contribute to the ETI.

In this paper, we explore the welfare effects of tax reforms in the presence of tax deductions. We hence focus on a specific adjustment channel which is common and important in all personal income tax systems across the world. For instance, in the US, itemized deductions represent about $12 \%$ of all taxable income, worth $\$ 80$ billion in total (Saez 2004a). ${ }^{1}$ Based on the framework of Chetty (2009), we show that the ETI is not a sufficient statistic if (i) claimed deductions generate externalities and (ii) if deductions are responsive to tax rate changes.

In general, governments allow for deduction possibilities in the tax law to encourage certain behavior or expenses that produce benefits - in the future or present. In other words, the rationale behind deductions usually is to incentivize

\footnotetext{
${ }^{1}$ The ratio of deductions to taxable income is even higher in Germany (see below). Deductions generally play an important role in all developed countries' personal income tax codes (Ernst \& Young 2013), suggesting that our results are not only relevant for Germany or the US.
} 
behavior that generates interpersonal or intertemporal externalities. For example, deductions in the form of charitable donations are transferred to another agent in the economy, implying that the amount deducted is not lost but serving society. Deductible investments in education or professional training will increase human capital leading to higher incomes and hence higher tax revenues in the future. Given the purpose and character of most deductions, we argue that the first condition for the ETI not to be a sufficient statistic is likely to be fulfilled: all well-designed and well-intended deductions generate non-negligible externalities. ${ }^{2}$

The second condition for a non-sufficient ETI is fulfilled if a non-zero deduction elasticity with respect to changes in the net-of-tax rate is estimated empirically. From a theoretical perspective, tax deductions should respond to tax rate changes given that a higher tax rate makes the claiming of tax deductions more attractive. In the empirical part of the paper, we test this hypothesis and examine the responsiveness of deductions to taxes. We use rich German panel data from administrative tax records that provide detailed information on all income tax relevant parameters including all available tax deductions.

We exploit variation in tax rates induced by various income tax reforms implemented in Germany in the early 2000s. These reforms affected different types of taxpayers differently. For instance, over this period, the top marginal tax rate decreased from $53 \%$ to $42 \%$ in several steps, and the lowest marginal tax rate from $24 \%$ to $15 \%$, while tax rates in the middle of the distribution where hardly affected. These differential reform intensities allow identification of the tax rate effect on deduction behavior. Given our research question, studying the case of Germany is of particular interest since the German tax system allows for a very large set of deductions: on average, taxable income is more than $20 \%$ lower than reported broad income with variation over the income distribution and by income source, and there are more than 500 different deduction possibilities (Kirchhof 2011). ${ }^{3}$

We start our empirical analysis with estimating tax elasticities for different income concepts (broad gross income vs. taxable income) and continue with the analysis for different types of deductions. The empirical identification of the impact of tax changes on deductions generally faces the same econometric challenges as the identification of the ETI: first, there exists a mechanical relationship between tax

\footnotetext{
${ }^{2}$ Despite generating positive externalities, some deductions may additionally incur welfare losses. For example, if extension possibilities lead to overconsumption, sheltering behavior will be associated with resource costs that reduce the economic pie. Welfare costs may also arise because of the opportunity costs of filing deductions.

${ }^{3}$ Bach et al. (2013) analyze the ratio of taxable income in reported broad income over time. Their findings are broadly in line with our numbers although they employ a different concept of broad income and use a different data source.
} 
deductions and tax rates in progressive tax systems, and second, mean reversion as well as heterogeneous income trends have to be accounted for. This motivates us to employ the same empirical strategy for the ETI and deduction elasticity estimations based on the frequently used instrumental variable (IV) methodology initiated by Gruber and Saez (2002). ${ }^{4}$

Our findings suggest a statistically significant elasticity of taxable income with respect to the net-of-tax rate of around 0.49. As most other studies, we find a lower elasticity of gross income (EGI); the estimate being not statistically different from zero. The results further show that the difference between ETI and EGI is driven by deductions that are indeed responsive to changes in the net-of-tax rate: the elasticity of deductions is estimated at -2.80 and statistically highly significant. We additionally show that the behavioral response is mainly due to (itemized) deductions which are relatively less likely to be third-party reported and where taxpayers are more likely to have a choice of claiming. Our results are robust to several sensitivity checks.

Given that deductions generate externalities, the strong response of deduction behavior to tax rates demonstrates that the ETI is not a sufficient statistic. Hence, our first contribution is to add to the literature discussing the ETI and its potential role as a sufficient statistic for welfare analysis. Besides the rather recent contributions by Chetty (2009) and Gorodnichenko et al. (2009), a series of earlier papers has identified revenue offset, i.e., shifting income to other tax bases, as a threat to the interpretation of the ETI as a sufficient statistic since revenue leakage in one base will induce revenue gains in another (Slemrod 1998; Gordon and Slemrod 2002; Slemrod and Yitzhaki 2002; Saez 2004b).

As our second contribution, we add to the literature by providing further information on the "anatomy of tax systems". ${ }^{5}$ As pointed out by Slemrod (1996), Saez (2003) or Saez et al. (2012), detailed knowledge about the different adjustment channels underlying the ETI is desirable because government has full control over the definition of taxable income. Knowing the responsiveness of its components can hence help to design (more) efficient tax systems. ${ }^{6}$ So far, direct evidence on the

\footnotetext{
${ }^{4}$ This literature is surveyed in Saez et al. (2012). Recent applications such as Chetty et al. (2011) or Kleven and Schultz (2014) also exploit local kinks in tax schedules to identify the ETI. Such an approach is, however, not applicable to the German case since there are no tax brackets in the German tax schedule.

${ }^{5}$ Our study is also related to the literature showing that charitable giving (donations being usually tax deductible) is responsive to income tax changes (see, e.g., Joulfaian 2000, Yörük 2013 and Andreoni 2006 for a survey).

${ }^{6}$ Among all possible adjustment channels that are summarized in the ETI, the responsiveness of labor supply has so far received the most attention in the literature finding modest behavioral elasticities in the range of 0 to 0.3 (see Blundell and MaCurdy 1999 and Bargain et al. 2014 for
} 
effect of taxes on tax deduction behavior is relatively scarce. Exceptions are Matikka (2014) who presents suggestive evidence from Finland that certain deductions are responsive to income taxes, and Bastani and Selin (2014) whose analysis points in the direction that taxable income responses of Swedish self-employed mainly occur through legal tax avoidance rather than labor supply adjustments. Moreover, Slemrod and Kopczuk (2002) and Kopczuk (2005) show that the ETI is considerably larger in tax systems with more deduction possibilities providing evidence that the ETI is not an immutable parameter but rather a policy choice (see, e.g., Slemrod 1994; Slemrod 1995; Slemrod 1998). There is also evidence that broad gross income is less responsive to tax changes than taxable income (Saez et al. 2012; Kleven and Schultz 2014). These studies indicate that the adjustment of tax deductions might be relevant, but they do not provide direct evidence that deduction behavior is responsive to tax rate changes since a smaller elasticity for broad than taxable income does not necessarily imply that deductions respond to tax rate changes as we show in Section 2.1.

Providing new ETI estimates for Germany is our third contribution. There are only a few studies that examine the ETI for Germany (Gottfried and Witczak 2009, Massarrat-Mashhadi and Werdt 2012, Schmidt and Müller 2012) which we extend by using a larger panel data set along with additional estimation methods. Besides the vast amount of deduction possibilities, the case of Germany is interesting because of the unique German tax schedule that does not have tax brackets but rather a tax formula that generates linearly increasing marginal tax rates over a large segment of the tax income distribution.

Our paper proceeds as follows. Section 2 presents the conceptual framework. We first present an extension of the Chetty (2009) model (2.1) and then present our empirical strategy (2.2). In Section 3, we describe the institutional background and the tax reforms that we exploit for identification. Section 4 informs about the data set we use and presents summary statistics. Our results are presented in Section 5. Section 6 discusses the results and concludes the paper.

surveys). Other channels that have been found to contribute to the ETI are, e.g., inter- and intratemporal income shifting (Auerbach and Slemrod 1997, Kreiner et al. 2013, Harju and Matikka 2013, Kreiner et al. 2014), or tax non-compliance (Gorodnichenko et al. 2009; Kleven et al. 2011). 


\section{Conceptual Framework}

\subsection{Theoretical Model}

Tax deductions are intended to either compensate (disadvantageous) individuals for distributional reasons (e.g., deductions for disabled people) or to encourage certain behaviors or expenses that generate benefits for society (Poterba 2011). Examples of the latter include charitable donations, the deduction of insurance fees to encourage the healthy to buy insurance or child-care costs to stimulate labor supply. Other deductions often exist to expense investments in human capital. Since the returns to human capital investments are fully taxed (in forms of higher income in later periods), there are no efficiency costs over the life-cycle if deducting investment costs leads to efficient investment decisions. Thus, deductions serve the purpose to incentivize taxpayers (by offering reductions in the tax burden) to behave in a way that produces externalities to society. Overall, it is, by definition, difficult to think of a deduction that is not associated with either an interpersonal or intertemporal transfer. ${ }^{7}$ As a consequence, taxable income adjustments in the form of deductions are likely to affect the available economic pie differently than other adjustment margins (e.g., tax evasion or labor supply). Deductions might even increase efficiency relative to an allocation in which the externalities of the deductible expense are not generated. If the value of each deduction (deductible amount times marginal tax rate) corresponded to the optimal Pigouvian subsidy, individuals would behave optimally and claim the socially optimal amount of deductions.

To study the effect of deduction possibilities more formally, we adopt the theoretical model developed by Chetty (2009) to the case of tax deductions. While Chetty's contribution has mostly been discussed in the context of tax evasion, his point is more general and his model can account for all different kinds of tax sheltering behavior. Let us assume that an individual chooses working hours $L$ and tax avoidance effort (in the form of claiming tax deductions) $D$ to maximize utility $U=U(C, L, D)$, where $C$ denotes consumption. There are economic opportunity costs (resource costs) of claiming deductions $g(D)$, which negatively affect utility. ${ }^{8}$ Utility is defined as $U=C-\psi(L)-g(D)$, where $\psi(L)$ denotes the disutility of

\footnotetext{
${ }^{7}$ Our static framework does not explicitly account for intertemporal transfers such as education investments from the present to the future. However, the intuition is similar since transfers over time do not decrease (the present value of) the economic pie. Hence, interpersonal transfers can be interpreted as intertemporal ones in this setting.

${ }^{8}$ These resource costs could be interpreted either as deviations from first-best, socially optimal behavior (because the value of the deduction $t \cdot D$ does not correspond to the optimal Pigouvian subsidy) or simply the opportunity costs in terms of, e.g., foregone leisure due to collecting deductions bills or understanding the tax code.
} 
labor. The budget constraint of the individual is determined by unearned income $Y$, labor income $w L$ with $w$ being a given wage, the purchase of deductions $D$ and a tax $t$ on labor income after deductions $w l-D: C+D+t(w L-D)=Y+w L .^{9}$ Thus, the individual solves the following maximization problem:

$$
\begin{array}{ll} 
& \max _{L, D} U=C-\psi(L)-g(D) \\
\text { s.t. } & C=Y+(1-t)(w L-D)
\end{array}
$$

First order conditions are given by:

$$
\begin{aligned}
(1-t) w & =\psi^{\prime}(L) \\
t & =g^{\prime}(D)+1
\end{aligned}
$$

showing that both labor supply and deduction claiming depend on the tax rate.

Social welfare $W$ is the sum of individual utility (in curly brackets), tax revenues $t(w L-D)$ and externality $e(D)$, which depends on deduction behavior:

$$
W(t)=\{Y+(1-t)(w L-D)-\psi(L)-g(D)\}+t(w L-D)+e(D)
$$

Besides specifying the individual costs of deducting directly as $D$, we also deviate from the original model by introducing the externality $e(D)$, which does not have to be identical to the costs of sheltering. Modeling the welfare function such that the sheltered amount $D$ is identical to the externality is, for example, appropriate for the case of tax evasion, in which the sheltered amount may generate a fine that directly enters the government's budget. In our case in which the sheltered amount is the tax deduction, it seems, however, appropriate that the deduction $D$ might have a different value for society than for the agent who claimed the deduction. Take a donation to a charitable organization as an example. It is likely that donations generate a welfare effect worth more or less than its money value, depending on the mission and the efficiency of the charitable organization. We will re-address this feature of the model in the concluding section of this paper.

\footnotetext{
${ }^{9}$ As opposed to Chetty (2009), who provides a micro-foundation of transfer costs using fines for tax evasion as an example, we assume that the costs of sheltering (here: purchase of a deduction) equal the actual amount spent on the deductible good or service. Hence, we simply use $D$ as the costs of deducting. In a more general case (or in the evasion example by Chetty), the costs of deducting could also be some function of the deduction amount, $z(D)$, and therefore be different from $D$. Note that our assumption does not change the results since the concrete specification of the costs of sheltering in the agent's budget constraint is irrelevant for the calculation of marginal welfare costs because of the envelope conditions.
} 
In order to arrive at the well-known ETI formula, we differentiate social welfare with respect to the tax rate $t$. Using the envelope theorem and the fact that taxable income $T I$ is gross income $G I$ minus deductions, $T I=G I-D=w L-D$, we derive the following formula for the marginal welfare effect of taxes:

$$
\frac{d W(t)}{d t}=t \frac{d T I}{d t}+\frac{d e}{d D} \frac{d D}{d t}
$$

which already shows that the ETI is not a sufficient statistic if deductions come with a transfer and are responsive to taxes (i.e., $\frac{d e}{d D} \frac{d D}{d t} \neq 0$ ). Defining the elasticities of taxable income and the deductions elasticity as $\varepsilon_{T I}=-\frac{d T I}{d t} \frac{1-t}{T I}$ and $\varepsilon_{D}=-\frac{d D}{d t} \frac{1-t}{D}$, respectively, we get

$$
\frac{d W(t)}{d t}=-\frac{1}{1-t}\left[t T I \varepsilon_{T I}+e^{\prime}(D) D \varepsilon_{D}\right]
$$

This expression reveals that $(i)$ if deductions exist $(D>0)$ and $(i i)$ if there are externalities $e$ that vary with deduction behavior $D\left(\frac{d e}{d D}=e^{\prime}(D) \neq 0\right)$ and $($ iii $)$ if deductions respond to tax rates $\left(\varepsilon_{D} \neq 0\right)$, the elasticity of taxable income, $\varepsilon_{T I}$, is not a sufficient statistic to calculate the welfare costs of marginal tax changes.

Note that several studies have interpreted differences in elasticities of broad and taxable income as suggestive evidence that deductions are responsive to tax rate changes. ${ }^{10}$ We argue that this does not have to be the case: the difference between reported gross income $G I$ and taxable income $T I$ is attributed to deductions, $T I=$ $G I-D$, so that $\frac{d T I}{d t}=\frac{d G I}{d t}-\frac{d D}{d t}$. This relationship can easily be used to show that

$$
\varepsilon_{T I}=\frac{G I}{T I} \varepsilon_{G I}-\frac{G I-T I}{T I} \varepsilon_{D}
$$

where elasticities are defined as above. This simple exercise illustrates that the elasticity of taxable income $\varepsilon_{T I}$ depends on the responsiveness of broad gross income, $\varepsilon_{G I}$, and deductions, $\varepsilon_{D}$, as well as the shares of broad gross income and deductions in taxable income, $\frac{G I}{T I}$ and $\frac{D}{T I}$. Note that $\frac{G I}{T I}$ is typically larger than one because some type of deductions or exemptions are usually subtracted from broad gross

\footnotetext{
${ }^{10}$ For example, Saez et al. (2012, page 39) state that "Gruber and Saez's elasticity estimate for broad income, 0.12 , is notably smaller than their corresponding estimate for taxable income, suggesting that much of the taxable income response comes through deductions, exemptions, and exclusions".
} 
income in any tax system. ${ }^{11}$ Hence, $\varepsilon_{T I}$ is larger than $\varepsilon_{G I}$ even if deductions were not responsive to tax rate changes, i.e., if $\varepsilon_{D}=0$. As a consequence, the conclusion that deduction behavior is responsible for differences between ETI and the elasticity of broad gross income is not necessarily valid.

We derive two main implications from our theoretical framework. First, according to expression (1), the ETI is not a sufficient statistic if there are tax deductions $(D \neq 0)$ that $(i)$ generate externalities $\left(e^{\prime}(D) \neq 0\right)$ and $(i i)$ are responsive to tax rate changes $\left(\varepsilon_{D} \neq 0\right)$. Second, in order to infer deduction behavior from the elasticities of gross and taxable income, it is not sufficient to compare the two elasticities but income shares have to be taken into account (see equation 2). In the empirical analysis, we, therefore, estimate the elasticities of gross and taxable income as well as the elasticity of tax deductions. This allows us to infer which components of taxable income are most responsive to taxes.

\subsection{Empirical Model and Identification}

This section describes the empirical model and outlines our identification strategy. In order to estimate the effect of the net-of-tax rate on different income or deduction measures, we employ the standard ETI panel regression model following Gruber and Saez (2002). For taxpayer $i$ in year $t$, we regress the change in our left-hand side variable of interest (either taxable income, gross income or deductions), $\Delta Y_{i, t}$, on changes in the marginal net-of-tax rate, $\Delta\left(1-\tau_{i, t}\right)$. The operator $\Delta$ indicates the difference between year $t$ and base-year $t-k$. In our baseline specification, we set $k=2$ as, e.g., in Chetty et al. (2011). Specifically, we estimate the following model:

$$
\Delta \ln Y_{i, t}=\varepsilon_{Y} \Delta \ln \left(1-\tau_{i, t}\right)+f\left(G I_{i, t-k}\right)+\phi \mathbf{X}_{i, t}+\gamma_{t}+\eta_{i, t}
$$

where $f\left(G I_{i, t-k}\right)$ is a function of individual base-year gross income, $\mathbf{X}_{i, t}$ a vector containing standard demographic variables (dummies for joint filing / marital status, number of children, and West- vs. East-Germany), $\gamma_{t}$ a set of year fixed effects and $\eta_{i, t}$ an individual error term. ${ }^{12}$

The coefficient of interest, $\varepsilon_{Y}$, can be directly interpreted as an elasticity since the outcome measure $Y_{i, t}$ and the net-of-tax rate $\left(1-\tau_{i, t}\right)$ enter the regression in logs. We follow standard practice in the literature to address potential threats to identification (Saez et al. 2012). First, we use panel data and estimate the model

\footnotetext{
${ }^{11}$ In Germany, $\frac{G I}{T I}$ is 1.26 on average, see Section 4 for more detailed summary statistics.

${ }^{12}$ Note that in our empirical specification we abstract from estimating income effects as this is common in the literature. See, e.g., Blomquist and Selin (2010) for a study allowing for income effects.
} 
in differences to wipe out time-invariant individual confounders. Second, following Auten and Carroll (1999), we account for mean reversion and secular trends in income inequality by controlling for base year income. Specifically, we add 10-piece splines of base-year gross income, $f\left(G I_{i, t-k}\right)$, in our baseline (as, e.g., in Chetty et al. 2011).

Third, we have to account for the mechanical relationship between our lefthand side variables and the net-of-tax rate in progressive tax systems. An increase in income automatically changes the net-of-tax rate because in progressive systems higher incomes are taxed at higher marginal tax rates. The same reasoning applies when tax deductions are used on the left-hand side of the equation: higher deduction claims reduce taxable income and therefore also affect the tax rate. This mechanical relationship between the left-hand side variables and $\left(1-\tau_{i, t}\right)$ requires to find an instrument for the net-of-tax rate that is unrelated to the error term in the above regression model. Following Gruber and Saez (2002), most studies in the literature use an instrument which is based on predicted changes in tax rates that are solely due to legislative tax reforms (e.g., Chetty et al. 2011 and Kleven and Schultz 2014). The net-of-tax rate in year $t$ is instrumented with the "synthetic" net-of-tax rate $\left(1-\tau_{i, t}^{\text {synth }}\right)$ that is constructed by applying the tax schedule in year $t$ to income in year $t-k$. As a result, the synthetic instrument only captures statutory tax rate changes caused by reforms while it abstracts from mechanical tax rate changes in progressive tax systems that are due to changing income (or deductions).

Fourth, mechanical effects induced by simultaneous tax rate and tax base reforms have important implications for the definition and construction of variables for our analysis. Note that this is a general problem of changing tax base definitions faced by most studies estimating the ETI. To circumvent this complication, the literature uses the broadest definition of the tax base (see Saez et al. 2012) when tax base changes occur at the same time as tax rate changes. We follow this approach in our paper. ${ }^{13}$

We estimate regression model (3) using two-stage least squares and cluster standard errors on the individual level. First-stage regressions (not shown) of $\Delta \ln \left(1-\tau_{i, t}\right)$ on $\Delta \ln \left(1-\tau_{i, t}^{\text {synth }}\right)$ are very strong with $F$-statistics exceeding 250. Figure 2 in the Appendix provides graphical evidence of the first stage (Panel A) and the reduced-form regression (Panel B) following the exposition of Weber (2014). More precisely, in panel A (B), the figure plots a fourth-order local polynomial regression of the change in the log marginal net-of-tax rate (log taxable income) on

\footnotetext{
${ }^{13}$ Note that using this broadest tax base approach might underestimate the responsiveness of deductions. The reason for this is that the broadest base might mask some behavioral responses in case of changes in cap limits or minimum amounts.
} 
the changes in the predicted log marginal net-of-tax rate. Looking at panel $\mathrm{A}$, the instrument is performing well even for large changes in the marginal net-of-tax rates as indicated by the narrow $95 \%$ confidence bands over the whole distribution of tax changes. Panel B indicates that the average taxable income change is increasing with predicted marginal net-of-tax rate changes.

\section{Institutional Background}

\subsection{The personal income tax in Germany}

All individuals in Germany are subject to personal income taxation. Residents are taxed on their global income; non-residents are taxed on income earned in Germany only. ${ }^{14}$ The basic steps for the calculation of the personal income tax under German tax law are illustrated by table 1 .

Table 1: Calculation of the personal income tax

\begin{tabular}{ll}
\hline \hline & Sum of broad gross income $(G I)$ from 7 sources (3 types of self- \\
& employment income; labor income; 3 types of capital income) \\
- & Income-related deduction $\left(D^{\text {income }}\right)$ \\
$=$ & Adjusted gross income $(A G I)$ \\
\hline$-\quad$ & Deductions and allowances \\
& for "Special expenses" and "Extraordinary burden" $\left(D^{\text {other }}\right)$ \\
$-\quad$ & Child allowance \\
$=$ & Taxable Income $(T I)$ \\
\hline & Tax formula \\
$=$ & Tax liability \\
\hline & Tax credits \\
$=$ & Tax due $(T)$ \\
\hline \hline
\end{tabular}

Broad gross income, GI. The first step is to determine a tax unit's broad gross income from different sources and to allocate it to the seven forms of income the German tax law distinguishes between: income from agriculture and forestry, business income, self-employment income, salaries and wages from employment, investment income, rental income, and other income (including, for example, annuities and certain capital gains). ${ }^{15} G I$ is used in our regression analyses to identify the sensitivity

\footnotetext{
${ }^{14}$ The legal norm setting up the German tax system is called Einkommensteuergesetz (EStG).

${ }^{15}$ The following types of income are tax exempt: payments from health insurance, accident insurance and insurance for disability and old age, welfare benefits and scholarships.
} 
of broad income.

Adjusted gross income, $A G I$. Second, for each type of income, the tax law allows for certain income-related expenses (Werbungskosten). In principle, all expenses that are necessary to obtain, maintain or preserve the income from a source are deductible. These include, for instance, commuting costs, expenses for work materials or costs of training. For non-itemizing taxpayers, there is an allowance for labor earnings (€920 in 2008) and capital income (€750 in 2008). The sum of broad gross income minus income-related deductions per income source yields the adjusted gross income.

Taxable income, $T I$. As a third step, further deductions are taken into account and subtracted from adjusted gross income yielding taxable income. These other deductions comprise special expenses (Sonderausgaben) and expenses for extraordinary burden (außergewöhnliche Belastungen). A detailed list of examples for other deductions is shown in Table 2. ${ }^{16}$ Moreover, negative income from the preceding assessment period (loss deduction carried back) can be subtracted from adjusted gross income. Last, each tax unit with children receives either a child allowance or a child benefit, depending on which is more favorable. We use TI as a dependent variable in the regressions to derive the ETI.

Deductions, D. The German personal income tax law allows for a vast number of potential deductions: According to Kirchhof (2011), there are "at least 534 different" deduction possibilities. First, as mentioned above, all income-related deductions, $D^{\text {income }}$, that are necessary to generate or earn income can be deducted. This includes, e.g., commuting costs or expenses to buy working clothes. In addition, expenses for mandatory public or voluntary private pension insurance, as well as health and unemployment insurance, can be deducted. Compared to other deductions, income-related deductions are more likely to be third-party reported and automatically deducted from the broad gross income. This implies that taxpayers often neither have a choice whether to make the expense nor whether to claim it on the tax return.

Second, other deductions, $D^{\text {other }}$, which are split into special expenses and extraordinary burden expenses can be deducted. These itemized deductions are typically self-reported and involve (much more) choices of the individual taxpayers. The former category includes expenses for investment in human capital (own education or professional training as well as expenses for education of children),

\footnotetext{
${ }^{16}$ In contrast to many other countries, mortgage interest payments are not tax deductible.
} 
Table 2: Overview of other (itemized) deductions

\begin{tabular}{ll}
\hline Category & \\
\hline & Alimony payments \\
& Church tax \\
& Tax consultant fees \\
& Expenses for professional training \\
& School fees of children \\
& Charitable donations \\
& Donations to political parties \\
& Insurance fees \\
& Social insurance contributions \\
\hline & Expenses for the education of dependents, for the cure \\
& of illness, for home help with elderly or disabled people, \\
& commuting expenses caused by disability \\
& Child care costs \\
& Tax allowances for self used proprietary, premises and \\
& historical buildings \\
& Allowances for disabled persons, surviving dependents \\
Expenses & and persons in need of care \\
\hline
\end{tabular}

child care costs, donations to charity or political parties and church tax payments. ${ }^{17}$ These examples show that "sheltering" in the form of tax deductions usually does not serve the purpose of maximizing after-tax income, but is instead intended to internalize externalities such as transfers to other agents in the economy or investments that yield higher taxable income in the future and are hence taxed later in the life-cycle. In our regressions, we use income-related deductions, $D^{\text {income }}$, other deductions, $D^{\text {other }}$, as well as their sum (called total deductions $D^{\text {total }}$ ) as dependent variables to estimate the deductions elasticity.

Tax due, $T$. The income tax is calculated by applying the tax schedule to taxable income. In contrast to most other countries who use a bracket system with constant marginal tax rates within a bracket, Germany uses a formula (which is quadratic in income) to compute the tax liability. As a consequence, marginal tax rates increase linearly in income (up to an top marginal tax rate of $42 \%$ ). The formula for the

\footnotetext{
${ }^{17}$ Extraordinary burden expenses, which are relatively unimportant in magnitude on average, grant taxpayers allowances in extraordinary circumstances: disabled persons, surviving dependents and persons in need of care.
} 
year 2008 is defined as follows ${ }^{18}$ :

$$
T= \begin{cases}0 & \text { if } T I \leq 7,664 \\ \left(883.74 \frac{T I-7,664}{10,000}+1,500\right) \frac{T I-7,664}{10,000} & \text { if } 7,664<T I \leq 12,739 \\ \left(228.74 \frac{T I-12,739}{10,000}+2,397\right) \frac{T I-12,739}{10,000}+989 & \text { if } 12,739<T I \leq 52,151 \\ 0.42 T I-7,914 & \text { if } 52,151<T I \leq 250,000 \\ 0.45 T I-15,414 & \text { if } T I>250,000 .\end{cases}
$$

In addition to the personal income tax, households additionally pay the "Solidaritätszuschlag", a tax supplement originally introduced to finance the German reunification. During the period of interest, 2000 - 2008, the supplement amounts to $5.5 \%$ of the income tax liability. ${ }^{19}$

\subsection{Reforms 2001-2008}

Figure 1 shows the marginal tax rate schedule for the years 2001-03, 2004 and 200508. Taxpayers with a high taxable income and those with a taxable income slightly exceeding the basic tax allowance experienced the largest marginal tax rate cuts. ${ }^{20}$ Between 2000 and 2005, a major reform of the German personal income tax took place. The basic tax allowance was increased in several steps from $€ 6902$ in 2000 to $€ 7664$ (2004-2008) with $€ 7206$ in 2001 and $€ 7235$ in 2002/03. The lowest marginal tax rate decreased from $22.9 \%$ in 2000 to $15 \%$ (2005-2008) with $19.9 \%$ (2001-03) and 16\% (2004) in between. The top marginal tax rate was reduced from $51 \%$ in 2000 to $42 \%$ in 2005 with $48.5 \%$ (2001-03) and $45 \%$ (2004) in between. The threshold where the top marginal tax rate kicks in was reduced from $€ 58,643$ in 2000 to $€ 52,151$ in 2004 with values of $€ 55,007$ (2001-03) in between. In 2007, an additional tax bracket at the top (for taxable income above $€ 250,000$ ) was introduced with a top marginal tax rate of $45 \%$. Tax rates in the medium range of the schedule were lowered as well.

\footnotetext{
${ }^{18}$ For married taxpayers filing jointly, the tax is twice the amount of applying the formula to half of the married couple's joint taxable income: $T\left(T I_{1}+T I_{2}\right)=2 * T\left(\frac{T I_{1}+T I_{2}}{2}\right)$.

${ }^{19}$ The exact rule is slightly more complicated with a minimum tax amount resulting in the kink visible in Figure 1 at roughly 15,000€ .

${ }^{20}$ Figure 3 in the Appendix plots the income distribution along the marginal tax rate schedule.
} 
Figure 1: Marginal tax rates

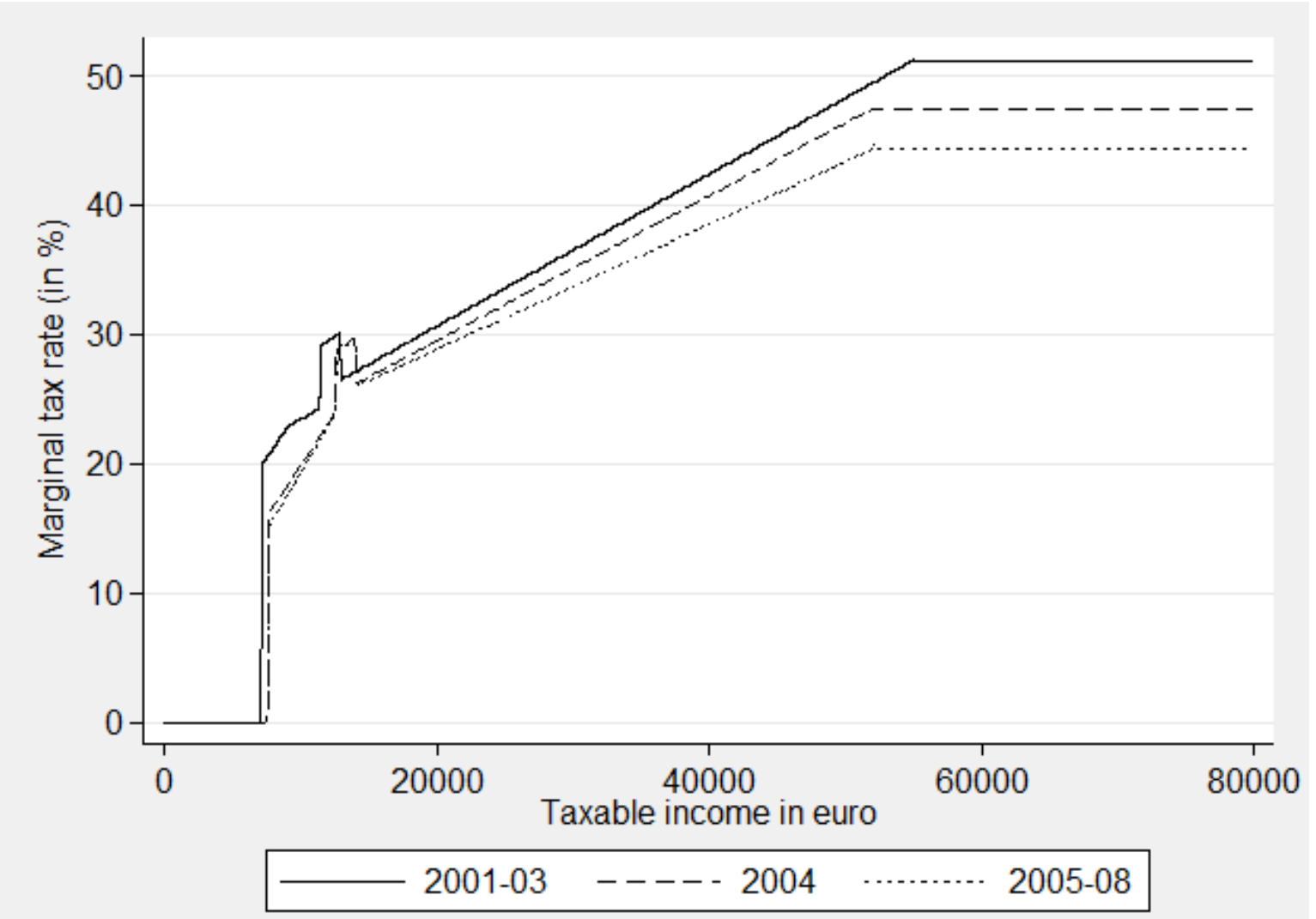

\section{Data and Summary Statistics}

Data set. We use the German Taxpayer Panel, which is an administrative data set collected by German tax authorities, provided and administered by the German Federal Statistical Office (Kriete-Dodds and Vorgrimler 2007). The unit of observation is the taxpayer, i.e., either a single individual or a couple filing jointly. The panel covers all German tax units in the period 2001 to 2008. We have access to a $5 \%$ random sample of the Taxpayer Panel and employ the respective weights provided by the Statistical Office. The dataset contains all information necessary to calculate a taxpayer's annual income tax, this includes basic socio-demographic characteristics such as birth date, gender, family status, number of children as well as detailed information on income sources and tax base parameters such as workrelated expenses and (claimed and realized) deductions.

Sample selection. We restrict our estimation sample to individuals who have a positive income above $€ 10,000$ (in real 2001 terms) in each period. We further exclude taxpayers who change their marital status throughout the sample period because this implies a change from individual to joint filing or vice versa, and re- 
strict the sample to individuals in the range of ages 18 to 65 (the pension age in Germany). We also have to exclude a few taxpayers with implausible demographic characteristics (e.g., change of gender or date of birth) that are due to data errors. These restrictions leave us with a sample of about 1.9 million observations. In line with the literature, our regressions are weighted with taxable income and the sample weights.

Summary Statistics. For our analysis, we look at 5 different dependent variables (see Sections 2.2 and 3.1): (1) taxable income TI, (2) broad gross income GI, (3) total deductions $D^{\text {total }}$, which consist of (4) income-related deductions $D^{\text {inc }}$ and (5) other deductions $D^{\text {other }}$ (with $D^{\text {total }}=D^{i n c}+D^{\text {other }}$ ). Table 4 in the Appendix shows descriptive statistics for these five variables. On average, the ratio between TI and GI is 0.79, which implies that total deductions account for about $20 \%$ of gross income. Comparing income-related and other deductions, the table shows that income-related expenses only make up for $12 \%$ of total deductions on average. Hence, other (itemized) deductions are relatively more important for the reduction of taxable income in Germany.

\section{Results}

This section presents regression evidence using all tax reforms between 2001 and 2008 for identifying variation. The results are based on equation (3) and stem from 2SLS regressions using the Gruber/Saez instrument. Table 3 depicts the regression estimates for different dependent variables. The dependent variables are two-year growth rates of taxable income $(T I)$, broad gross income $(G I)$, total deductions $\left(D^{\text {total }}\right)$, income-related deductions $\left(D^{i n c}\right)$, and other deductions $\left(D^{\text {other }}\right)$ (see section 3.1 for more information on the definitions of these variables).

Panel A of Table 3 depicts our baseline estimates where we regress two-year differences in our log dependent variables on two-year differences in the log marginal net-of-tax rate, instrumented with the standard Gruber and Saez (2002) synthetic tax rate change (as, e.g., in Chetty et al. (2011)). We estimate a highly significant elasticity of taxable income of 0.49 (I). The elasticity of gross income is considerably lower and not significantly different from zero (II). Comparing our results to the literature, we find that our ETI estimates are broadly in line with recent studies using similar models and estimators (Chetty 2009; Weber 2014; Kleven and Schultz 2014).

As many other previous studies, we also find that the elasticity of gross income is significantly lower than the ETI. However, our study is the first to explore explic- 
Table 3: ETI and deduction elasticities

\begin{tabular}{|c|c|c|c|c|c|}
\hline & (I) & (II) & (III) & (IV) & $(\mathrm{V})$ \\
\hline Dependent Variable & $T I$ & $G I$ & $D^{\text {total }}$ & $D^{i n c}$ & $D^{\text {other }}$ \\
\hline \multicolumn{6}{|c|}{ Panel A: Baseline specification } \\
\hline \multirow{2}{*}{$\Delta \log (1-\tau)$} & $0.490^{* * *}$ & 0.009 & $-2.785^{* * *}$ & $-0.080^{* *}$ & $-3.192^{* * *}$ \\
\hline & $(15.67)$ & $(0.38)$ & $(-49.32)$ & $(-2.42)$ & $(-49.99)$ \\
\hline$F-S t a t$ & 300.8 & 300.8 & 307.3 & 297.6 & 300.8 \\
\hline$N$ & $1,432,094$ & $1,432,094$ & $1,417,867$ & $1,329,497$ & $1,432,017$ \\
\hline \multicolumn{6}{|c|}{ Panel B: Baseline specification with additional income controls } \\
\hline \multirow[t]{2}{*}{$\Delta \log (1-\tau)$} & $0.330^{* * *}$ & 0.033 & $-1.825^{* * *}$ & 0.006 & $-2.113^{* * *}$ \\
\hline & $(9.34)$ & $(1.18)$ & $(-30.99)$ & $(0.16)$ & $(-30.92)$ \\
\hline$F-S t a t$ & 275.2 & 275.2 & 281.0 & 272.5 & 275.2 \\
\hline$N$ & $1,185,604$ & $1,185,604$ & $1,173,006$ & $1,099,115$ & $1,185,544$ \\
\hline \multicolumn{6}{|c|}{ Panel $\boldsymbol{C}$ : Baseline specification with three-year growth rates } \\
\hline \multirow[t]{2}{*}{$\Delta \log (1-\tau)$} & $0.364^{* * *}$ & $0.051^{*}$ & $-1.942^{* * *}$ & $0.128^{*}$ & $-2.261^{* * *}$ \\
\hline & $(9.69)$ & $(1.87)$ & $(-32.22)$ & $(1.84)$ & $(-33.79)$ \\
\hline$F-S t a t$ & 417.9 & 417.9 & 423.2 & 409.7 & 417.9 \\
\hline$N$ & $1,186,233$ & $1,186,233$ & $1,174,648$ & $1,099,299$ & $1,186,169$ \\
\hline \multicolumn{6}{|c|}{ Panel D: Baseline specification with Weber (2014) instrument } \\
\hline \multirow[t]{2}{*}{$\Delta \log (1-\tau)$} & $1.014^{* * *}$ & $0.356^{* * *}$ & $-3.567^{* * *}$ & -0.008 & $-4.010^{* * *}$ \\
\hline & $(11.72)$ & $(5.86)$ & $(-23.05)$ & $(-0.10)$ & $(-23.67)$ \\
\hline$F-S t a t$ & 302.3 & 302.3 & 300.1 & 288.2 & 302.3 \\
\hline$N$ & $1,185,685$ & $1,185,685$ & $1,173,054$ & $1,099,153$ & $1,185,624$ \\
\hline
\end{tabular}

Notes: 2SLS regressions based on equation (3) with t-statistics in parentheses. Standard errors clustered on the taxpayer level. Significance levels are ${ }^{*}<0.10,{ }^{* *}<0.05,{ }^{* * *}<0.01$. German tax return data for 2001-2008. Results are based on a 5\% random sample of the universe of German taxpayers. Dependent variables in all panels are (I) taxable income TI, (II) broad gross income $G I$, (III) total deductions $D^{\text {total }}$, (IV) income-related deductions $D^{\text {inc }}$ and (V) other (itemized) deductions $D^{\text {other }}$. All dependent variables are logged. Independent variable of interest is the twoyear growth rate in the marginal net-of-tax rate (i.e., $\Delta \log (1-\tau)$ ), instrumented with the two-year growth rate in the synthetic net-of-tax rate based on base-year $t-2$ behavior (Gruber/Saez-type instrument). Reported coefficients can be interpreted as elasticities identified from tax reforms. All specifications include year fixed effects, region fixed effects (East vs. West Germany), controls for demographic variables (Dummies for number of children, marital status) as well as 10-piece splines in logged base-year income. The sample is restricted to tax units with taxable income above $€ 10,000$ (in real 2001 terms), who are 18-65 years old and do not change their filing status throughout the sample period. All specifications are weighted with taxable income and provided sample weights. F-Stat indicates the first-stage F-statistic and $N$ is the number of observations. Panel A is the baseline specification as described. Panel B adds income controls specified as 10-piece splines based on the log-deviation between base-year and base-year +1 income (following Kopczuk 2005). Panel C uses three-year growth rates instead of two-year growth rates. Panel D uses a Weber (2014)-type instrument where the instrument is based on behavior in the year prior to base-year $t-3$.

itly whether responsive deductions are the reason for this difference in elasticities. Columns (III) to (V) show that, as expected, deductions respond negatively to in- 
creases in the net-of-tax rate. For the sum of all deductions $D^{\text {total }}$, we estimate a highly significant elasticity of -2.785 . This effect is driven by (itemized) other deductions $D^{\text {other }}(\mathrm{V})$ rather than income-related deductions $D^{i n c}(\mathrm{IV})$ for which we estimate a very low elasticity. This is reassuring given that taxpayers have much more discretion whether to claim (itemized) $D^{\text {other }}$-type deductions, while income-related deductions $D^{i n c}$ are often automatically accounted for and third-party reported.

We conduct several robustness checks to make sure that our estimates are not driven by modeling choices. In a first step, we additionally include 10-piece splines based on the log deviation between base-year and base-year +1 income in our specifications, as suggested by Kopczuk (2005) and recently applied in Kleven and Schultz (2014). The inclusion of the second set of splines is intended to control better for transitory income components. Estimates in Panel B show that elasticities decrease slightly in absolute terms but the general pattern does not change. Most importantly, deductions are still found to be very responsive to tax rate changes.

Next, in Panel C, we regress three-year growth rates in our dependent variable on three-year changes in the log net-of-tax rates as, e.g., in Kleven and Schultz (2014), instead of using two-year differences. Again, estimates are hardly affected.

Last in Panel D, we address recent concerns that the Gruber/Saez synthetic instrument is not exogenous (see, e.g., Weber 2014 or Blomquist and Selin 2010). Although it is possible to control for base-year income in flexible ways (e.g., by including income splines), it is not clear if any correlation between the Gruber/Saez instrument and the error term is controlled for. We hence apply an approach recently suggested by Weber (2014), in which the synthetic tax rate is based on a lag of base-year income, e.g., $t-k-1$, instead of base-year income $t-k$ as in Gruber and Saez (2002). This approach reduces, and ideally abolishes, the correlation between the error term and the instrument. Panel D shows that using this plausibly more exogenous instrument yields significantly higher elasticity estimates. This is well in line with the original application of the estimation strategy in Weber (2014). Again, the general pattern of our baseline specification is preserved. In particular, gross income responds less than taxable income and deductions remain to be very sensitive to tax rate changes, which is main empirical contribution of this paper (independent of the exact magnitudes of the elasticity estimates).

\section{Conclusion}

In this paper, we show both theoretically and empirically that the ETI is not a sufficient statistic for analyzing the welfare effects of tax reforms in the presence of tax 
deductions. Our theoretical framework reveals that the ETI is not the appropriate welfare parameter if $(i)$ deductions generate externalities and $(i i)$ deductions are responsive to tax rate changes. While the first condition holds in arguably all cases, we use German tax return data to demonstrate empirically that deductions respond negatively to net-of-tax rates, implying that the second condition holds as well.

Given that most tax systems around the world allow for deduction possibilities, the findings in our paper cast doubt on the merits of using the ETI to design optimal tax systems in practice. We show that instead of the ETI, a combination of the ETI, the deduction elasticity and the marginal externality of deducting expenses determines the marginal costs of a tax increase. The challenge for researchers, therefore, is to develop research designs that allow to estimate not only the ETI and deduction elasticity, but also to identify the marginal externality and the responsiveness of tax deductions. While this paper provides a set of results on the former measures, the question of how to empirically pin down the marginal externality is yet to be answered. ${ }^{21}$

Recalling equation (1), $\frac{d W(t)}{d t}=-\frac{1}{1-t}\left[t T I \varepsilon_{T I}+e^{\prime}(D) D \varepsilon_{D}\right]$, we can, nevertheless, try to assess how relevant the presence of deduction possibilities is for the interpretation of the ETI as a sufficient statistic. In particular, the relative difference between the first and the second part of the term in brackets (normalized by gross income) is crucial: $t \frac{T I}{G I} \varepsilon_{T I}$ versus $e^{\prime}(D) \frac{D}{G I} \varepsilon_{D}$. Using mean values from table 4 , and our central estimates of ETI and deduction elasticities $\left(\varepsilon_{T I}=0.490\right.$ and $\left.\varepsilon_{D^{\text {total }}}=-2.785\right)$ and assuming a marginal tax rate $t$ of 0.3 (sample mean), we get 0.12 for the first and $-0.56 \cdot e^{\prime}(D)$ for the second term. Even if we assume that every euro deducted (and thus transferred to a third agent) is worth only half its money value, i.e. $e^{\prime}(D)=0.5$, the additional marginal welfare costs induced by accounting for deducting behavior (the second term) is larger (in absolute terms) than the costs if the ETI was a sufficient statistic (the first term). Note that these numbers may be particularly large in Germany for two reasons. First, there are vast deductions possibilities in Germany leading ceteris paribus to a relatively large second term - especially if a taxpayer decides to hire a professional tax preparer. Second, the peculiar German tax schedule that has no brackets and therefore hardly any kink points is likely to yield low real responses to tax rate changes, which is also indicated by the low elasticity of gross income that we estimate. Nevertheless, the simple back-of-the-envelope calculation shows that the presence of deduction possibilities are likely to lead to marginal deadweight costs of taxation, which are

\footnotetext{
${ }^{21}$ Note that Chetty (2009) derives the welfare loss as a weighted average of the ETI and the EGI. However, estimating the weight, i.e., the marginal resource cost of sheltering in his model, is also not trivial (see, e.g., the concluding discussion in Chetty 2009).
} 
quite different from the estimates using the well-known ETI formula.

Another important question which we did not address in the present paper is how to optimally design tax deductions. As argued above, most (if not all) deduction possibilities exist to internalize externalities. In order to have no welfare consequences, i.e. not to distort optimal behavior of agents, the value of the deduction, i.e. $t \cdot D$, has to correspond to the optimal Pigouvian subsidy. It is hard to imagine that tax policy makers manage to set this optimal deduction level for every single deduction possibility. Analyzing this could hence be a fruitful avenue for future research. 


\section{References}

Andreoni, J. (2006). Philanthropy. In S.-C. Kolm and J. Mercier Ythier (Eds.), Handbook of the Economics of Giving, Altruism and Reciprocity (1 ed.), Volume 2. Elsevier.

Auerbach, A. J. and J. Slemrod (1997). The Economic Effects of the Tax Reform Act of 1986. Journal of Economic Literature 35(2), 589-632.

Auten, G. and R. Carroll (1999). The effect of income taxes on household income. Review of Economics and Statistics 81(4), 681-693.

Bach, S., G. Corneo, and V. Steiner (2013). Effective taxation of top incomes in germany. German Economic Review 14, 115 - 137.

Bargain, O., K. Orsini, and A. Peichl (2014). Comparing Labor Supply Elasticities in Europe and the US: New Results. Journal of Human Resources 49(3), 723838.

Bastani, S. and H. Selin (2014). Bunching and non-bunching at kink points of the swedish tax schedule. Journal of Public Economics 109(0), 36 - 49.

Blomquist, S. and H. Selin (2010). Hourly wage rate and taxable labor income responsiveness to changes in marginal tax rates. Journal of Public Economics 94(11-12), 878-889.

Blundell, R. and T. MaCurdy (1999). Labor Supply: A Review of Alternative Approaches. In O. Ashenfelter and D. Card (Eds.), Handbook of Labor Economics, Volume 3A, Chapter 27. Elsevier North-Holland.

Chetty, R. (2009). Is the taxable income elasticity sufficient to calculate deadweight loss? the implications of evasion and avoidance. American Economic Journal: Economic Policy 1(2), 31-52.

Chetty, R., J. N. Friedman, T. Olsen, and L. Pistaferri (2011). Adjustment costs, firm responses, and micro vs. macro labor supply elasticities: Evidence from danish tax records. The Quarterly Journal of Economics 126(2), 749-804.

Ernst \& Young (2013). Worldwide Personal Tax Guide 2013 2014. EYGM Limited.

Feldstein, M. (1995). The effect of marginal tax rates on taxable income: A panel study of the 1986 Tax reform act. Journal of Political Economy 103(3), 551.

Feldstein, M. (1999). Tax avoidance and the deadweight loss of the income tax. Review of Economics and Statistics 81(4), $674-680$. 
Gordon, R. and J. Slemrod (2002). Are 'real' responses to taxes simply income shifting between corporate and personal tax bases? In J. Slemrod (Ed.), Does Atlas Shrug? The Economic Consequences of Taxing the Rich, pp. 240-280. New York: Harvard University Press and Russell Sage Foundation.

Gorodnichenko, Y., J. Martinez-Vazquez, and K. S. Peter (2009). Myth and reality of flat tax reform: Micro estimates of tax evasion response and welfare effects in Russia. Journal of Political Economy 117(3), pp. 504-554.

Gottfried, P. and D. Witczak (2009). The Responses of Taxable Income Induced by Tax Cuts. Empirical Evidence from the German Taxpayer Panel. IAW Diskussionspapier Nr. 57.

Gruber, J. and E. Saez (2002). The elasticity of taxable income: evidence and implications. Journal of Public Economics 84 (1), 1-32.

Harju, J. and T. Matikka (2013). The elasticity of taxable income and incomeshifting between tax bases: what is "real" and what is not? Working Papers 1313, Oxford University Centre for Business Taxation.

Joulfaian, D. (2000.). Estate Taxes and Charitable Bequests by the Wealthy. National Tax Journal 53(3), 743-764.

Kirchhof, P. (2011). Bundessteuergesetzbuch. Ein Reformentwurf zur Erneuerung des Steuerrechts. Heidelberg: C.F. Müller Wissenschaft.

Kleven, H. and E. Schultz (2014). Estimating taxable income responses using danish tax reforms. American Economic Journal: Economic Policy. forthcoming.

Kleven, H. J., M. B. Knudsen, C. T. Kreiner, S. Pedersen, and E. Saez (2011). Unwilling or unable to cheat? evidence from a tax audit experiment in denmark. Econometrica 79(3), 651-692.

Kopczuk, W. (2005). Tax bases, tax rates and the elasticity of reported income. Journal of Public Economics 89(11-12), 2093-2119.

Kreiner, C. T., S. Leth-Petersen, and P. E. Skov (2013). Tax Reforms and Intertemporal Shifting of Wage Income: Evidence from Danish Monthly Payroll Records. CEPR Discussion Paper No. 9697.

Kreiner, C. T., S. Leth-Petersen, and P. E. Skov (2014). Year-End Tax Planning of Top Management: Evidence from High-Frequency Payroll Data. American Economic Review, Papers and Proceedings 104 (5), 154-158.

Kriete-Dodds, S. and D. Vorgrimler (2007). The German Taxpayer-Panel. Schmollers Jahrbuch 127(3), 497-509. 
Massarrat-Mashhadi, N. and C. Werdt (2012). Estimating dynamic income responses to tax changes: Evidence from Germany. Free University Berlin Discussion Papers Nr. 2012/22.

Matikka, T. (2014). Taxable income elasticity and the anatomy of behavioral response: Evidence from Finland. Technical report, Government Institute for Economic Research Working Papers No. 55.

Poterba, J. (2011). Economic Analysis of Tax Expenditure. NBER and Chicago University Press.

Saez, E. (2003). The effect of marginal tax rates on income: a panel study of "bracket creep". Journal of Public Economics 87(5-6), 1231-1258.

Saez, E. (2004a). The optimal treatment of tax expenditures. Journal of Public Economics 88(12), 2657 - 2684.

Saez, E. (2004b, February). Reported incomes and marginal tax rates, 1960-2000: Evidence and policy implications. Working Paper 10273, National Bureau of Economic Research.

Saez, E., J. Slemrod, and S. H. Giertz (2012). The elasticity of taxable income with respect to marginal tax rates: A critical review. Journal of Economic Literature 50(1), 3-50.

Schmidt, T.-P. and H. Müller (2012). Die Elastizität des zu versteuernden Einkommens in Deutschland. ARQUS Discussion Paper Nr. 132.

Slemrod, J. (1994). Fixing the leak in Okun's bucket - Optimal tax progressivity when avoidance can be controlled. Journal of Public Economics 55, 41-51.

Slemrod, J. (1995). Income creation or income shifting? behavioral re- sponses to the tax reform act of 1986. American Economic Review Papers and Proceedings 85(2), 175-180.

Slemrod, J. (1996). High income families and the tax changes of the 1980s: The anatomy of behavioral response. In F. M. and J. Poterba (Eds.), Empirical Foundations of Household Taxation, pp. 169-192. University of Chicago Press.

Slemrod, J. (1998). Methodological Issues in Measuring and Interpreting Taxable Income Elasticities. National Tax Journal 51(4), 773-788.

Slemrod, J. and W. Kopczuk (2002). The optimal elasticity of taxable income. Journal of Public Economics 84(1), 91-112.

Slemrod, J. B. and S. Yitzhaki (2002). Tax avoidance, evasion, and administration. In A. J. Auerbach and M. S. Feldstein (Eds.), Handbook of Public 
Economics, Volume 3, pp. 1423-1470. Amsterdam: Elsevier Science Publishers.

Weber, C. (2014). Toward obtaining a consistent estimate of the elasticity of taxable income using difference-in-differences. Journal of Public Economics 117, 90-103.

Yörük, B. K. (2013). The impact of charitable subsidies on religious giving and attendance: Evidence from panel data. Review of Economics and Statistics 95(5), 1708-1721. 


\section{A Appendix}

Table 4: Descriptive statistics for dependent variables

\begin{tabular}{lcccccc}
\hline Variable & mean & sd & $\mathrm{p} 10$ & $\mathrm{p} 25$ & $\mathrm{p} 75$ & $\mathrm{p} 90$ \\
\hline$G I$ & 55,484 & 150,912 & 25,630 & 31,842 & 61,264 & 87,824 \\
$T I$ & 43,919 & 148,714 & 16,838 & 22,439 & 47,115 & 72,164 \\
$D^{\text {total }}$ & 11,565 & 10,225 & 2,869 & 5,281 & 15,987 & 21,274 \\
$D^{\text {inc }}$ & 1,402 & 6,012 & 920 & 920 & 1,840 & 2,522 \\
$D^{\text {other }}$ & 10,164 & 7,881 & 1,744 & 4,077 & 14,235 & 19,090 \\
\hline
\end{tabular}

Notes: Summary statistics for variables that are used as dependent variables in the regressions. Gross income $G I$, taxable income $T I$, total deductions $D^{\text {total }}$, income-related deductions $D^{i n c}$, other (itemized) deductions $D^{\text {other }}$ (where $D^{\text {total }}=D^{\text {inc }}+D^{\text {other }}$ ). German tax return data for 2001-2008. Statistics are based on a representative 5\% sample of the universe of German taxpayers. All money variables in 2001 euro. $N=1,996,200$. Means and standard deviations (sd). $p X$ indicates the X-th percentile. 
Figure 2: First-stage and reduced form
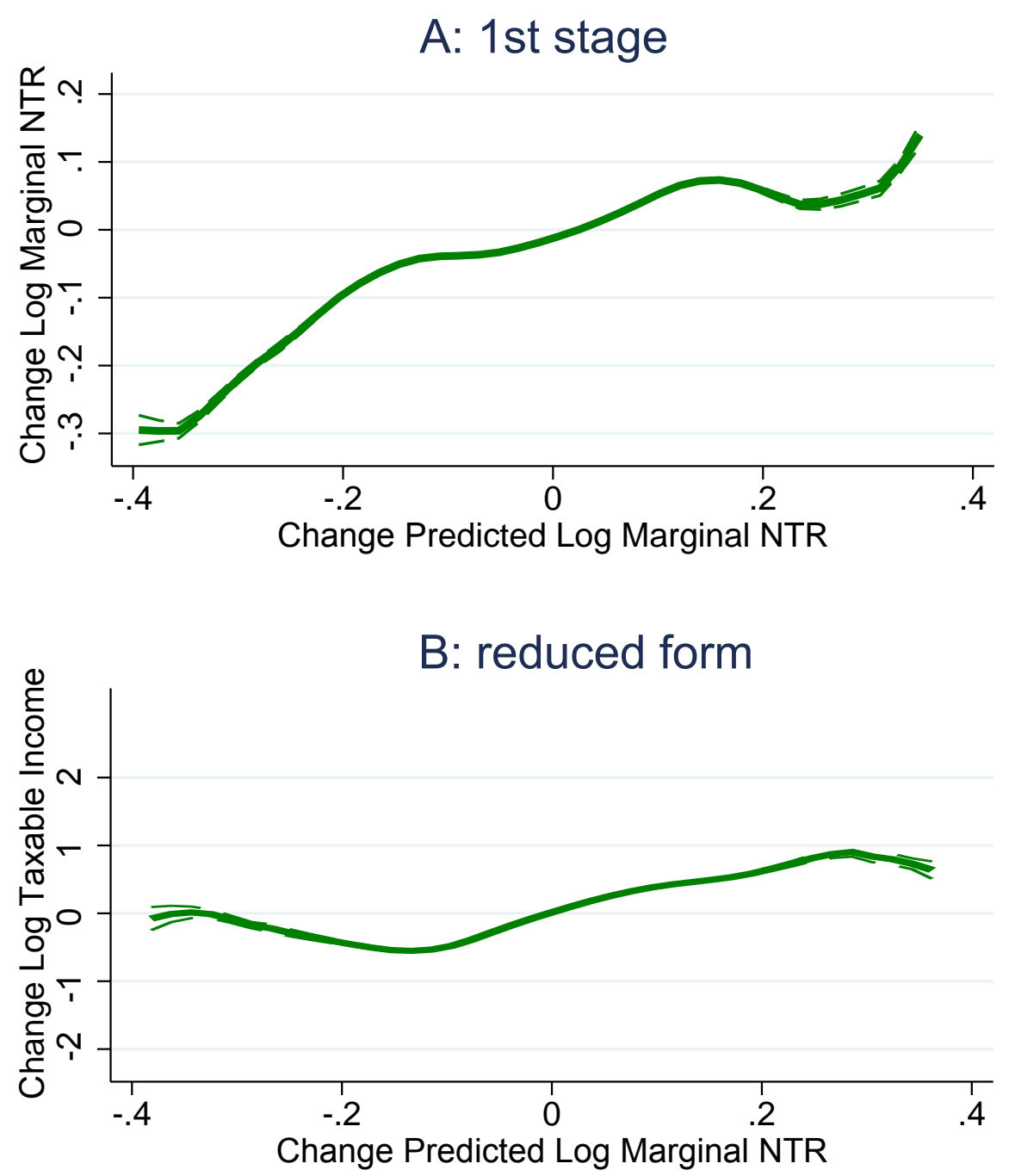

Notes: Graphical evidence of the first-stage and reduced-form regressions. German tax return data for 2001-2008. Graphs are based on a 5\% sample of the universe of German taxpayers. Panel A plots a fourth-order local polynomial regression of the change in the $\log$ marginal net-of-tax rate (log taxable income) on the changes in the predicted log marginal net-of-tax rate. Panel B is based on a fourth-order local polynomial regression of the change in log taxable income on the changes in the predicted log marginal netof-tax rate. The dashed lines are $95 \%$ confidence intervals. The graphical illustration is based on Weber (2014). 
Figure 3: Marginal tax rates and income distribution

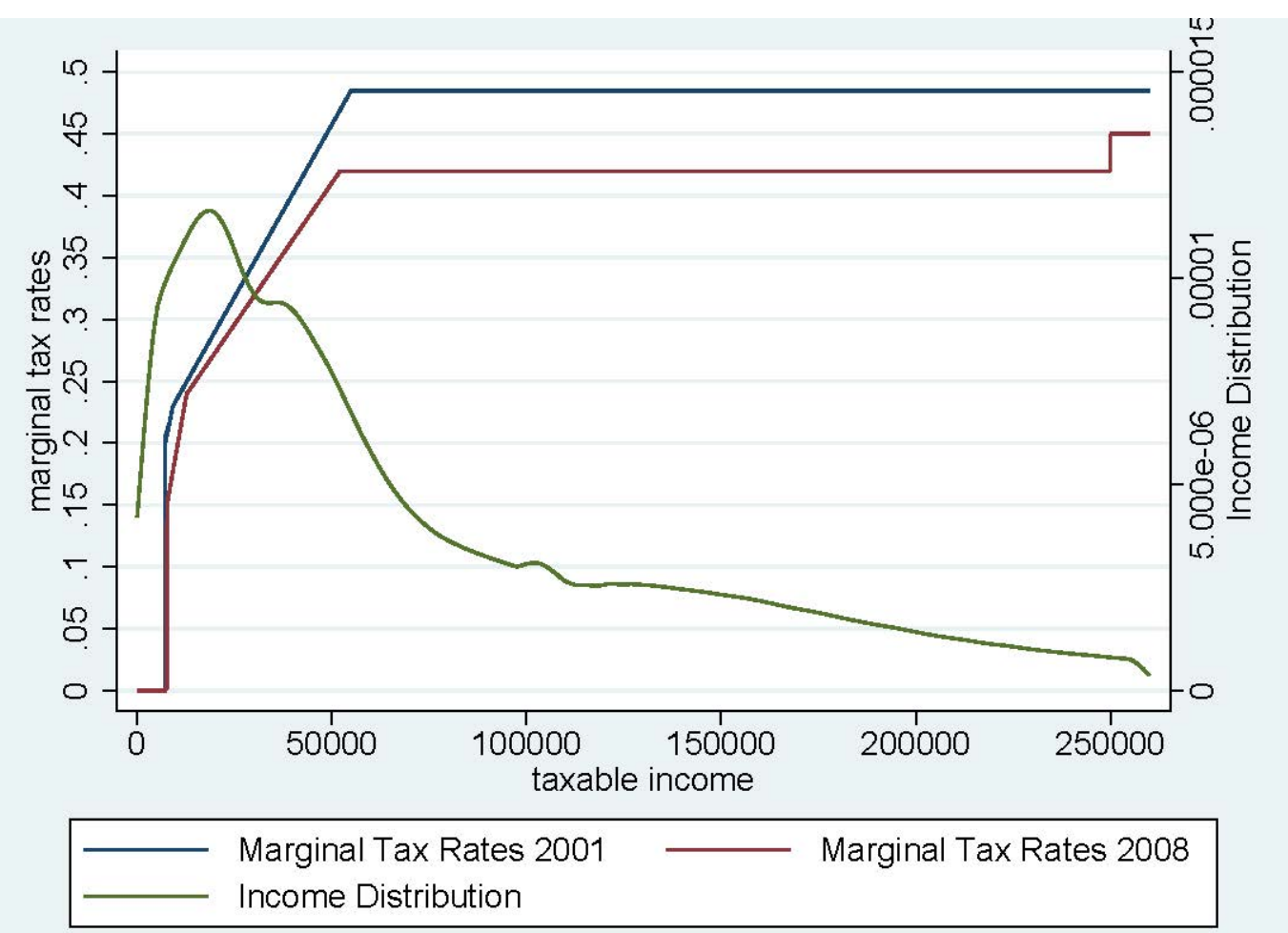

Notes: Marginal tax rates in 2001 and 2008 and income distribution in 2001. 